\title{
Exploring the effects of pre-task planning time on EFL learners' narrative writing
}

\section{Explorar los efectos del tiempo de planificación en la redacción na- rrativa de estudiantes de inglés}

\author{
Arezoo Ashoori Tootkaboni \\ Allameh Tabataba'i University \\ Maryam Pakzadian \\ Isfahan University of Medical Sciences
}

\begin{abstract}
The present study is carried out in order to provide deeper insights into the differential effects of pre-task planning time conditions on Iranian EFL learners' narrative writing production (accuracy, fluency, and complexity). To this end, three intact classes comprising $70 \mathrm{EFL}$ language learners, studying in private language institutes in Iran, were randomly assigned to either no pre-task planning, 5 minute pre-task planning or 10 minute pre-task planning conditions. Analysis of the written narratives and the results of a series of one-way ANOVA revealed that both $5 \mathrm{mi}-$ nute and 10 minute pre-task planning groups showed substantial progress compared to those in the no pretask planning group regarding the accuracy, fluency and complexity of their output. The obtained results support the view that providing pre-task planning opportunities leads task performers to produce the kind of output which displays improved complexity, accuracy, and fluency. The results also have some implications for teachers and practitioners in EFL contexts.
\end{abstract}

Keywords: Pre-task planning; Complexity; Fluency; Accuracy; Written narratives

\section{Resumen}

El presente estudio se llevó a cabo con el fin de proporcionar información sobre los efectos del tiempo de planificación previa a la tarea en la escritura narrativa de estudiantes de inglés como lengua extranjera iraníes (precisión, fluidez y complejidad). Con este objetivo, 70 estudiantes de tres clases de institutos de idiomas privados en Irán fueron asignadas al azar a grupos sin tiempo de planificación, con 5 minutos de planificación o con 10 minutos de planificación. El análisis de las narrativas escritas y los resultados de los análisis ANOVA unidireccionales revelaron que los grupos que tuvieron 5 o 10 minutos de planificación previa a la tarea mostraron un progreso sustancial en comparación con el grupo sin tiempo de planificación en cuanto a la precisión, fluidez y complejidad de su producción. Los resultados obtenidos sugieren que proporcionar oportunidades de planificación previa a la tarea resulta en mejor complejidad, precisión y fluidez. Los resultados también tienen algunas implicaciones para el profesorado.

Palabras clave: Planificación previa a la tarea; Complejidad; Fluidez; Precisión; Narrativas escritas 


\section{INTRODUCTION}

Over the last two decades, task-based language teaching has been the focus of second language acquisition researchers for both pedagogical and research perspectives (e.g. Abdi Tabari, 2017; Ahmadian \& Tavakoli, 2011; Ellis, 2009; Kim \& Tracy-Ventura, 2013; Nasiri \& Atai, 2017). Due to the effectiveness of task-based approaches in providing a context for improving natural language learning, a considerable number of studies have been carried out to investigate its different aspects (e.g. Ahmadian, 2012; Ahmadian, Tavakoli, \& Vahid Dastjerdi, 2015; Baleghizadeh \& Nasrollahi Shahri, 2013; Markee \& Kunitz, 2013; Ong, 2014).

One of the research lines which has received a attention from researchers and language teachers is the role of pre-task planning time on performing a task. It is regarded as a processing condition before the main task which plays an important role in language learners' performance (Ellis, 2005). Since planning is linked with the role of attention in language learning and it directly influences language learners in terms of what they produce (Ellis, 2005), a large number of studies have focused on the interaction between these two, such as comparing pre-task planning and online planning (e.g. Ghavamnia, Tavakoli, \& Esteki, 2013; Yuan \& Ellis, 2003) or pre-task planning alone (e.g. Kawauchi, 2005; Ojima, 2006; Ong, 2014).

The way planning affects language production is both theoretically and practically important to language researchers and teachers (Ellis, 2005). It is considered to be a kind of strategy that emancipates learners from stressful conditions in communication (Sangarun, 2001), shifts learners' attention away from language forms (Van Patten, 1990), and permits them to process the information at a more meaningful and deeper level (Wendel, 1997). Since planning plays an important role in task performance, plenty of studies have concentrated on the interplay between planning and language learners' oral task performance (Ahmadian et al., 2015; Ellis, 2005, 2009; Mochizuki \& Ortega, 2008; Skehan \& Foster, 1997; Yuan $\&$ Ellis, 2003). However, to date, a paucity of literature exists regarding the influences of planning time conditions on complexity, accuracy and fluency in writing tasks, particularly in EFL contexts. This study strives to address the current gaps in planning research by exploring how pre-task planning might influence advanced EFL learners' textual performance as measured along the dimensions of complexity, accuracy, and fluency. 


\section{BACKGROUND OF THE STUDY}

\section{Accuracy, complexity, and fluency}

Skehan (1996, p. 46) defines accuracy as the "learner's capacity to handle whatever level of interlanguage complexity s/he has currently attained". He further claims that trying to produce more accurate language means seeking control over the language forms that a learner has already learned. Thus, in trying to produce more accurate language, learners are more engaged with controlled rather than automatic processing. Additionally, since controlled processing proceeds the automatic one (McLaughin \& Heredia, 1996), it is safe to argue that accuracy is indispensable for developing automatic language. Skehan also identifies complexity as concerned with "the stage and elaboration of the underlying interlanguage system" (1996, p. 46). Finally, fluency deals with "the learner's capacity to mobilize an interlanguage system to communicate meaning in real time" (Skehan, 1996, p. 46). In other words, trying to produce more fluent language means giving priority to meaning rather than form (Ellis \& Barkhuizen, 2005). One of the major debates regarding complexity, fluency, and accuracy are the trade-off effects among them. They come into a competition with one another for attentional resources (Skehan, 1996) and due to limited processing capacity learners prioritize one aspect of their performance at the expense of the other features.

\section{Types of task planning}

Planning is an integral part of language production which is mainly classified into pre-task and within-task planning (Ellis, 2005). The former refers to planning before performing a task, while the latter occurs on-line and while performing a task. Pre-task planning also takes two forms: rehearsal (i.e. planning to perform a task completely before performing it for the second time) or strategic (planning the needed content or language for performing a task without having an opportunity to practice it). Within-task planning can be further divided into two parts: pressured (i.e. there is a time limit for performing a task) or unpressured (i.e. the learners have an unlimited amount of time for performing the task).

\section{Studies done on planning time}

Planning time has been considered as a processing condition whose role, especially in terms of language fluency and complexity in language production, cannot be ignored. By providing planning time in performing different task types, favorable results have been gained so far (Abdi Tabari, 2016; Amadian, 2012; Ellis 
\& Yuan, 2004; Li, Chen, \& Sun, 2014; Sangarun, 2005; Tavakoli \& Skehan, 2005; Wang, 2008; Yuan \& Ellis, 2003). Studies with different lengths of planning time have also been conducted, such as 15 minutes (Sangarun, 2005), 10 minutes (Gilabert, 2007; Yuan \& Ellis, 2003), 5 minutes (Tavakoli \& Skehan, 2005), 3 minutes (Williams, 1992), and 1 minute (Mehnert, 1998).

One of the most perceptive inquiries into pre-task planning time is Foster and Skehan's (1996) study, in which the effects of two variables, task design and processing condition, on oral performance of three different task types were measured: decision making, narrative and personal information exchange tasks. The no planning group was characterized as the one with more pauses and of greater length compared with the guided planning group, who were the more fluent speech producers. Furthermore, the unguided planning group was more fluent than the no planning group. Mixed results were also obtained for participants' accuracy. With increasing pre-task planning time, learners' accuracy also increased. The only exception was observed in the narrative, guided planning condition.

In a study conducted by Yuan and Ellis (2003), they operationalized three planning groups, online planning, no planning, and pre-task planning, to perform an oral narrative task. In line with previous studies, they found that while pre-task planning enhanced the complexity and lexical density of learners' production, it had no significant effects on their accuracy. On the other hand, whereas online planning and no pre-task planning did not have positive effects on learners' lexical variety, they were effective in promoting their complexity and especially their accuracy. Concerning the group with unlimited time, it was found that their fluency was low, but by drawing on their explicit knowledge they could reformulate and self-correct and consequently enhance their accuracy. Their results also confirmed the trade-off effect among accuracy, complexity, and fluency. They stated that planning tasks prior to performing them helps learners to improve the fluency of their performance, and if they have time to plan online while performing a task, they would be more attentive to the accuracy rather than the fluency of their performance.

In an attempt to explore the effect of the interaction between proficiency and pre-task planning on task performance, Kawauchi (2005) asked 39 Japanese learners with different proficiency levels to complete some oral narrative tasks. Kawauchi (2005) found that strategic planning had positive consequences on the complexity, accuracy and fluency of oral narratives. Although greater complexity was found in the planned performance of all groups, it seemed less beneficial to the 
advanced EFL group. Concerning the fluency of the participants' performance, task planning had greater effects on the fluency of the high-intermediate EFL group than the low-intermediate and advanced EFL groups. Taking the accuracy of the narratives into consideration, the low-intermediate EFL group benefited significantly from the opportunity to plan. On the whole, planning improved the fluency and complexity of the high-intermediate EFL group, and the accuracy of the low-intermediate EFL group. Moreover, planning was more advantageous to the high and low-intermediate EFL groups than to the advanced ones.

Employing a case study, Mochizuki and Ortega (2008) examined the effect of the type of planning on learners' accuracy. To this end, they asked first-year Japanese high school students learning English to perform an oral story-retelling task under one of three conditions, i.e. no planning, 5 minutes unguided planning, or 5 minutes guided planning. The accuracy measurements were frequency of use and degree of accurate use of relative clauses. The results of their research showed that guided-planning participants produced more accurate relative clauses in their narratives than unguided or no planning groups.

In order to examine the effect of planning on second language (L2) learners' oral performance in a testing context, $\mathrm{Li}$ et al. (2014) investigated the effects of different lengths of pre-task planning time ( 30 seconds, 1 minute, 2 minutes, 3 minutes, and 5 minutes) on L2 learners' oral test performance regarding both the quality and quantity of the participants' linguistic production. The findings revealed that the provision of planning time positively influenced both the quantity and quality of oral production. To have a better and more detailed understanding, accuracy improved the most, with 1 minute planning time being the threshold that led to most improvement. Concerning different planning lengths, a positive effect of planning was not always observed in corroboration with the extension of time. In other words, too short a time (e.g. 30 seconds) was insufficient for improvement, whereas too long a time (e.g. 5 minutes) generated a diminishing effect.

Research has mainly focused on learners' oral production (e.g. Ahmadian et al., 2015, Elder \& Iwashita, 2005; Kawauchi, 2005; Li et al., 2015; Skehan, 1996; Yuan \& Ellis, 2003). Nevertheless, research on planning in writing contexts is quite scant, and there is no solid evidence to show that pre-task planning enhances EFL learners' written output in the ways that many researchers have announced for ESL contexts.

Moreover, although the obtained results reveal the clear and positive effects of planning on fluency and complexity of language learners' performance (e.g. Ellis 
\& Yuan, 2004; Foster \& Skehan, 1996; Yuan \& Ellis, 2003), the results have not yet been homogeneous in terms of the positive influence of pre-task planning on enhancing learners' accuracy (supported by Ellis \& Yuan, 2004; Yuan \& Ellis, 2003). These facts highlight that more studies are indeed required to fill these gaps. Therefore, the present study has been conducted to explore the effect of length of pre-task planning time on fluency, accuracy and complexity of Iranian EFL learners' written performance. For the purpose of this investigation, the following research questions were posed:

1. Does length of pre-task planning time have any effect on learners' written performance in terms of accuracy?

2. Does length of pre-task planning time have any effect on learners' written performance in terms of fluency?

3. Does length of pre-task planning time have any effect on learners' written performance in terms of complexity?

\section{METHODOLOGY}

\section{Participants}

The present study was carried out with 70 Iranian intermediate EFL learners studying in a private language institute in Iran. They met three times a week for one and half hours for a total number of 20 sessions. The participants were all native speakers of Farsi, aged between 17 to 35 and none of them had been to any Englishspeaking countries prior to the study. The participants were from three intact classes, comprising 21 to 25 in each, that were randomly assigned to one of the treatment conditions: i.e., no planning, 5 minute pre-task planning, and 10 minute pretask planning.

\section{Instruments}

\section{Pre-test materials}

In order to ascertain the participants are truly homogeneous in their language proficiency, a sample of TOEFL test was administered. Comparison of mean differences and one-way ANOVA revealed that there was no significant difference across the three treatment groups. Therefore, it could be claimed that the participants had equivalent language proficiency levels. It should also be pointed out that only the grammar section of the test was administered and the subjects' responses were rated on a scale of 100 points. Descriptive statistics and ANOVA results are presented in Tables 1 and 2 . 
Table 1. Descriptive statistics in terms of learners' proficiency level

\begin{tabular}{ccccc}
\hline Grouping & N & Mean & $\begin{array}{c}\text { Std. } \\
\text { Deviation }\end{array}$ & $\begin{array}{c}\text { Std. Error } \\
\text { Mean }\end{array}$ \\
\hline 10PP & 21 & 51.70 & 8.61 & 2.72 \\
5PP & 25 & 54.36 & 14.95 & 4.50 \\
NPP & 24 & 50.30 & 8.19 & 2.59 \\
\hline
\end{tabular}

Table 2 One-way ANOVA for participants' written accuracy across the three groups

\begin{tabular}{cccccc}
\hline & $\begin{array}{c}\text { Sum of } \\
\text { Squares }\end{array}$ & df & $\begin{array}{c}\text { Mean } \\
\text { Square }\end{array}$ & F & Sig. \\
\hline $\begin{array}{c}\text { Between } \\
\text { Groups }\end{array}$ & 90.09 & 2 & 45.04 & .35 & .7 \\
$\begin{array}{c}\text { Within } \\
\text { Groups }\end{array}$ & 3508.74 & & 67 & 125.31 & \\
\hline Total & 3598.73 & 69 & & \\
\hline
\end{tabular}

The results of the descriptive statistics revealed that the three experimental groups gained similar scores in regard to their mean scores: 10 minute pre-task planning group $(\overline{\mathrm{x}}=51.70), 5$ minute pre-task planning group $(\overline{\mathrm{x}}=54.36)$, and no pre-task planning group $(\bar{x}=50.30)$. In order to check the significance of the differences, One-way ANOVA was run.

As it is clear, the results showed that there was no significant difference among the three experimental groups concerning their language proficiency, $\mathrm{F}$ (.35), $\mathrm{p}=.70>.05$. Subsequently, it can be concluded that the three groups had equivalent English proficiency.

\section{Narrative Picture Story}

To fulfill the aim of the study, a narrative picture story consisting of eight pictures was adopted from Referential Communication Tasks by Yule (1997) (see Appendix). A narrative task was selected for a number of reasons. First, to make it more comparable with other studies done previously (e.g. Abdollahzadeh \& Fard Kashani, 2011; Ishikawa, 2006; Tavakoli \& Foster, 2011). Second, because of the monologic nature of written narratives and their easy control, they better assist us in inferring measures of learner performance that are not affected by interactional factors (Ortega, 1999). 


\section{Procedure}

As stated above, in the present study, planning was operationalized at three levels: no pre-task planning, 5 minute pre-task planning, and 10 minute pre-task planning. Operationalization of planning time was based on previous studies (e.g. Skehan \& Foster, 1997; Mehnert, 1998). Before conducting the main study, a pilot study was carried out to assign a time limit in order to curtail the online planning effect (Yuan \& Ellis, 2003). To this end, six students were selected to carry out the task. In addition, to further increase the pressure on the students, they were asked to write at least 250 words. It took between 16 to 19 minutes to narrate the pictures, with a mean of 17.5 minutes. Subsequently, it was decided to give the participants 18 minutes to complete the task. During writing, they had no interaction with each other and they were seating separately.

Concerning no pre-task planning group, the participants were given 18 minutes and they were asked to start writing immediately after distributing the pictures. In regard to 5 minute pre-task planning group, having been provided with the pictures, the participants were given 5 minutes in order to plan their performance of the task on a piece of paper. It is noteworthy to mention that the participants were not provided with any guidance, they were only reminded to be careful about the language, content, and organization of their text. Following Ellis and Yuan (2004), the written notes were removed upon the completion of pre-planning time to make sure that the participants produced the language exclusively in the specified time limit, i.e. 18 minutes.

In the 10 minute pre-task planning condition, the participants went through the same process as those in the 5 minute pre-task planning group. The only difference lied in the length of pre-task planning time.

\section{Data analysis}

Three production measures, i.e. accuracy, fluency, and complexity, were utilized to detect the variations across three conditions. The operationalization of these measures is provided below.

\section{Accuracy Measure}

Following Larsen-Freeman (2006), the accuracy of the participants' performance was operationalized as the number of error-free T-units to the total number of Tunits. According to Richards, Platt and Platt (1996), T-units include the main clause along with any subordinate clause. 


\section{Complexity Measure}

The complexity of the participants' written production was measured by calculating the percentage of dependent clauses to total number of clauses (following Wigglesworth \& Storch, 2009).

\section{Fluency Measure}

In terms of fluency, the number of words per T-units was calculated (following Arent, 2003; Ishikawa, 2006).

\section{RESULTS}

To estimate the effect of different pre-task planning time length on improving learners' fluency, accuracy and complexity of written performance, a series of one-way ANOVAs along with descriptive statistics were carried out. Table 3 presents the descriptive statistical results.

Table 3. Descriptive statistics for learners' narrative writing across the three groups

\begin{tabular}{ccccc}
\hline \multicolumn{5}{c}{ Accuracy } \\
\hline Grouping & N & Mean & $\begin{array}{c}\text { Std. } \\
\text { Deviation }\end{array}$ & $\begin{array}{c}\text { Std. Error } \\
\text { Mean }\end{array}$ \\
\hline 10PP & 21 & 72.10 & 15.01 & 4.74 \\
5PP & 25 & 71.64 & 14.74 & 4.44 \\
NPP & 24 & 57.00 & 11.12 & 3.51 \\
\hline & \multicolumn{5}{c}{ Complexity } \\
\hline 10PP & 21 & 34.90 & 5.34 & 1.69 \\
5PP & 25 & 32.27 & 5.79 & 1.74 \\
NPP & 24 & 30.40 & 9.60 & 3.03 \\
\hline & \multicolumn{5}{c}{ Fluency } & .70 \\
\hline 10PP & 21 & 15.10 & 2.23 & .70 \\
5PP & 25 & 14.00 & 2.32 & .66 \\
NPP & 24 & 11.20 & 2.09 &
\end{tabular}

As it can be seen in Table 3, the mean of the 10PP group ( $\overline{\mathrm{x}}=72.10)$ was higher than those in the 5PP $(\bar{x}=71.64)$ and NPP groups $(\bar{x}=57)$ in the case of accuracy. Concerning complexity, the 10PP group $(X=34.90)$ performed better than the $5 P P(\bar{x}=32.27)$ and NPP groups $(\bar{x}=30.40)$. Finally, in terms of the fluency results, learners in the 10PP group $(\bar{x}=15.10)$ displayed a better mean score compared to the two other groups: 5PP $(\bar{x}=14)$, and NPP $(\bar{x}=11.20)$. In order to find out the significance of these differences and where these differences lied, one-way 
ANOVAs and Sheffe tests were run for each measurement aspect (i.e. accuracy, fluency, and complexity) whose results are presented in Tables 4 and 5 .

Table 4. One-way ANOVA for participants' written accuracy across the three groups

\begin{tabular}{|c|c|c|c|c|c|}
\hline & $\begin{array}{l}\text { Sum of } \\
\text { Squares }\end{array}$ & df & $\begin{array}{l}\text { Mean } \\
\text { Square }\end{array}$ & $F$ & Sig. \\
\hline $\begin{array}{c}\text { Between } \\
\text { Groups }\end{array}$ & 2753.551 & 2 & 1376.776 & 7.67 & .002 \\
\hline $\begin{array}{l}\text { Within } \\
\text { Groups }\end{array}$ & 5025.545 & 67 & 179.484 & & \\
\hline Total & 7779.097 & 69 & & & \\
\hline
\end{tabular}

As Table 4 displays, there was a significant difference among the three experimental groups concerning the accuracy of their written performance, $\mathrm{F}$ (7.67), $\mathrm{p}=.002<.05$. To check where the differences lied, a Sheffe test was run whose results are presented in Table 5 .

Table 5. Sheffe test of differences across the groups (Accuracy)

\begin{tabular}{cccc}
\hline Grouping & Grouping & $\begin{array}{c}\text { Mean } \\
\text { difference }\end{array}$ & Sig. \\
\hline \multirow{2}{*}{ 10PP } & 5PP & .46 & .99 \\
& NPP & $24.40^{*}$ & .008 \\
5 SPP & 1OPP & $19.93^{*}$ & .99 \\
& NPP & -.46 & .008 \\
NPP & 10PP & -24.40 & .008 \\
& 5PP & $-19.93^{*}$ & .008 \\
\hline
\end{tabular}

As illustrated in Table 5, the participants in both the 10PP and 5PP groups outperformed those is the NPP one. Additionally, no significant differences were found between the performance of the learners in 10PP and 5PP groups. Their performance concerning the fluency of their production is presented in Tables 6 and 7.

Table 6. One-way ANOVA for participants' written fluency across the three groups

\begin{tabular}{cccccc}
\hline & $\begin{array}{c}\text { Sum of } \\
\text { Squares }\end{array}$ & df & $\begin{array}{c}\text { Mean } \\
\text { Square }\end{array}$ & F & Sig. \\
\hline $\begin{array}{c}\text { Between } \\
\text { Groups } \\
\text { Within }\end{array}$ & 81.17 & 2 & 40.58 & 8.20 & .002 \\
Groups & 138.50 & 67 & 4.94 & & \\
\hline Total & 219.67 & 69 & & & \\
\hline
\end{tabular}


From the results presented in the above table, it can be construed that there is a significant discrepancy among the experimental groups regarding the fluency of their written production, $\mathrm{F}(8.206), \mathrm{p}=.002<.05$. To check where the differences exactly lied, a Sheffe test was run. The results are presented in Table 7.

Table 7. Sheffe test of differences across the groups (Fluency)

\begin{tabular}{cccc}
\hline Grouping & Grouping & $\begin{array}{c}\text { Mean } \\
\text { difference }\end{array}$ & Sig. \\
\hline \multirow{2}{*}{$10 P P$} & 5PP & 1.10 & .53 \\
& NPP & $3.90^{*}$ & .002 \\
$5 P P$ & $10 P P$ & -1.10 & .53 \\
& NPP & $2.80^{*}$ & .02 \\
NPP & 10PP & $-3.90^{*}$ & .002 \\
& 5PP & $-2.80^{*}$ & .02 \\
\hline
\end{tabular}

In terms of the fluency measure, the Sheffe test indicated that both pre-planning groups gained significantly better results in comparison to the no-planning group. Similar to the previous one, no significant difference was found between the participants of 5 and 10 pre-task planning conditions. Tables 8 and 9 depict the complexity measure outcomes.

Table 8. One-way ANOVA for participants' complexity across the three groups

\begin{tabular}{cccccc}
\hline & $\begin{array}{c}\text { Sum of } \\
\text { Squares }\end{array}$ & df & $\begin{array}{c}\text { Mean } \\
\text { Square }\end{array}$ & F & Sig. \\
\hline $\begin{array}{c}\text { Between } \\
\text { Groups }\end{array}$ & 471.870 & 2 & 235.935 & 8.064 & .002 \\
$\begin{array}{c}\text { Within } \\
\text { Groups }\end{array}$ & 819.227 & 67 & 29.258 & & \\
\hline Total & 1291.09 & 69 & & & \\
\hline
\end{tabular}

The statistics presented in this table indicate there is a significant difference among the experimental groups regarding the complexity of their written production, $\mathrm{F}(8.064), \mathrm{p}=.002<.05$. To find out where exactly the differences lied, a Sheffe test was run whose results are presented in Table 9.

As depicted in Table 9, both the 5PP and 10PP groups gained significantly better results in comparison to the NPP group. However, differences between the two groups with the pre-planning condition did not reach the level of statistical significance, suggesting that complexity of written narratives benefited from careful pre-planning conditions. 
Table 9. Sheffe test of differences across the groups (Complexity)

\begin{tabular}{cccc}
\hline Grouping & Grouping & $\begin{array}{c}\text { Mean } \\
\text { difference }\end{array}$ & Sig. \\
\hline \multirow{2}{*}{ 10PP } & 5PP & 3.045 & .44 \\
& NPP & $9.500^{*}$ & .002 \\
5 SPP & $10 P P$ & -3.045 & .44 \\
& NPP & $6.455^{*}$ & .03 \\
NPP & $10 P P$ & $9.500^{*}$ & .002 \\
& 5PP & $-6.455^{*}$ & .03 \\
\hline
\end{tabular}

\section{DISCUSSION}

The present study examined the effects of applying different pre-task planning time lengths on EFL learners' written output. The dependent variables measured in this study were accuracy (operationalized as the number of error-free T-units to the total number of T-units), fluency (operationalized as the number of English words per T-units) and complexity (operationalized as the number of dependent clauses to total number of clauses). The analysis of data revealed that although there was a significant difference between the performances of those in the no pre-task planning group and the other two groups with pre-task planning conditions, providing different time length for pre-task planning yielded no significant differences in their productions in terms of accuracy, complexity and fluency.

In terms of the first research question, the obtained results indicate that whenever learners are provided with some time to organize their thoughts before task completion, their performance significantly improves in terms of the accuracy of their production. However, studies reported in the literature do not identify a stable pattern or relationship between these two variables. Some studies support the role of pre-task planning time on improving learners' accuracy (e.g. Foster \& Skehan, 1996; Kawauchi, 2005; Skehan \& Foster, 1997; Tavakoli \& Skehan, 2005; Yuan \& Ellis, 2003), while the others (e.g. Crooks, 1989; Iwashita, Elder, \& McNamara, 2001) did not find results to support such a claim.

One plausible explanation for the positive effects of pre-planning on enhancing the accuracy of language learners is provided by Dekeyser (2003). Based on Dekeyser's (2003) argumentation, during careful planning participants employ their explicit knowledge and as a result, are able to produce sentences with more accurate structures. On the other hand, under pressured online planning conditions they are likely to use their implicit language repertoire. This seems to be a 
reasonable hypothesis considering the argument that producing language under time pressure induces speakers to access and consult their implicit knowledge.

In regard to the second question, the efficacy of pre-task planning time on increasing learners' fluency in written narratives, the findings lend support to previous research such as Foster and Skehan (1996), Kawauchi (2005), Sangarun (2005), and Yuan and Ellis (2003), which showed that providing learners with pretask planning led to more fluency. Nevertheless, corroborating Wigglesworth's (1997) study, the statistical analyses did not divulge any significant improvement in terms of the complexity of participants' output in all experimental conditions. There are numerous reasons that can explain these results.

First, the positive effects of the pre-task planning time on enhancing fluency of L2 learners' written performance can be interpreted in terms of the processing load theory (Sangarun, 2005). Based on this theory, strategic planning lightens the processing load, and enables the conceptualizers to operate in a parallel form, i.e. it facilitates conceptualization and, as a result, the subjects would be able to produce more fluent output in pre-task planning experimental conditions. Widening this view, processing load theory can justify why native speakers seem more fluent than non-native ones. To put it simply, since L1 speakers possess ready-made plans as a result of being in different linguistic situations, they are able to plan subconsciously and automatically (Færch \& Kasper, 1983). In contrast, due to lack of such a ready-made repertoire, non-native speakers experience disfluency during their task performance.

Secondly, in light of Yuan and Ellis' (2004) argumentation, pre-task planning leads learners to more success in setting goals and organizing the content of their output. By setting a clear goal and specifying the content of their output, the processing load would be decreased during task performance. In a similar vein, Khomeijani Farahani and Meraji (2011) postulated that this can be due to the fact that learners try to write, practice, and review their intended content in pre-task planning time, hence, during real performance, their cognitive load diminishes and they can produce more fluent spoken or written performance.

Regarding the role of pre-task planning on the complexity of the learners' written narratives, the results of the present study neatly fits with the findings of Ahmadian et al. (2015), Ahmadian and Tavakoli (2011) and Ellis and Yuan's (2004) studies in which the two planning groups (i.e. pre-task and online groups) outperformed those in the no pre-task planning condition. Theoretically, the results can be explained in light of Skehan's (1998) dual-mode system proposal. According 
to Skehan (1998), learners under pressured online planning conditions are more likely to use their exemplar-based system which consists of a large number of readymade chunks of language and imposes lower degrees of cognitive demand on them. This might in turn reduce the speakers' creativity and readiness to employ newly learnt grammatical structures for creating novel sentences. Nonetheless, under careful online planning conditions, since learners have enough time for planning their task, they are likely to draw on their rule-based system. Skehan (1998) further explains that the rule-based system consists of generative linguistic rules which enables learners to utilize their novel linguistic knowledge and as a result produce more complex language.

An important note to be taken up is that, in line with Mehnert's (1998) study in which no significant difference was found between 3 minute and 10 minute planners, the present study also confirmed that 5PP and 10PP groups performed equally on all measures, i.e. accuracy, fluency, and complexity. Therefore, it can be inferred that 5 minute planning would be sufficient in achieving desirable outcomes and maintaining learners' interest at the same time.

\section{CONCLUSION}

This study was an attempt to investigate the effects of pre-planning on accuracy, complexity, and fluency of EFL learners' written production. The major contribution of this study to the existing literature is that pre-task planning has a positive impact on improving EFL learners' accuracy, fluency and complexity in regard to their written narratives. It can be concluded that due to some limitations in language learners' attentional resources, learners may not maintain balance among all aspects of the language development. So, teachers should selectively lead learners' attention to weak points of their production. If not, learners would prosper in some areas and lack in some other aspects. The results also provide pedagogical implications for language tests. As Yuan and Ellis (2003) believed, tests should provide L2 learners with opportunities for pre-task planning in order to present their best performance, thus allowing testers a better evaluation of learners' writing production.

In spite of the potential contribution of this study to task-based writing research, some limitations need to be acknowledged. First, given the multifaceted nature of the three principal constructs, using multiple measures for assessing each dimension of performance, i.e. complexity, accuracy, and fluency, is highly recommended (Ellis \& Barkhuizen, 2005). However, this study is rather limited in terms of the measurement of these constructs. Future studies, thus, need to utilize more 
measures of analysis to assess these constructs. Moreover, since the participants of the current study were selected among those studying at intermediate level in private language institutes, caution should be taken when generalizing the results to broader populations of language learners in Iran or other EFL settings.

\section{APPENDIX}

Look at the picture story below and write a narrative story starting with picture 1 and ending with picture 8 .
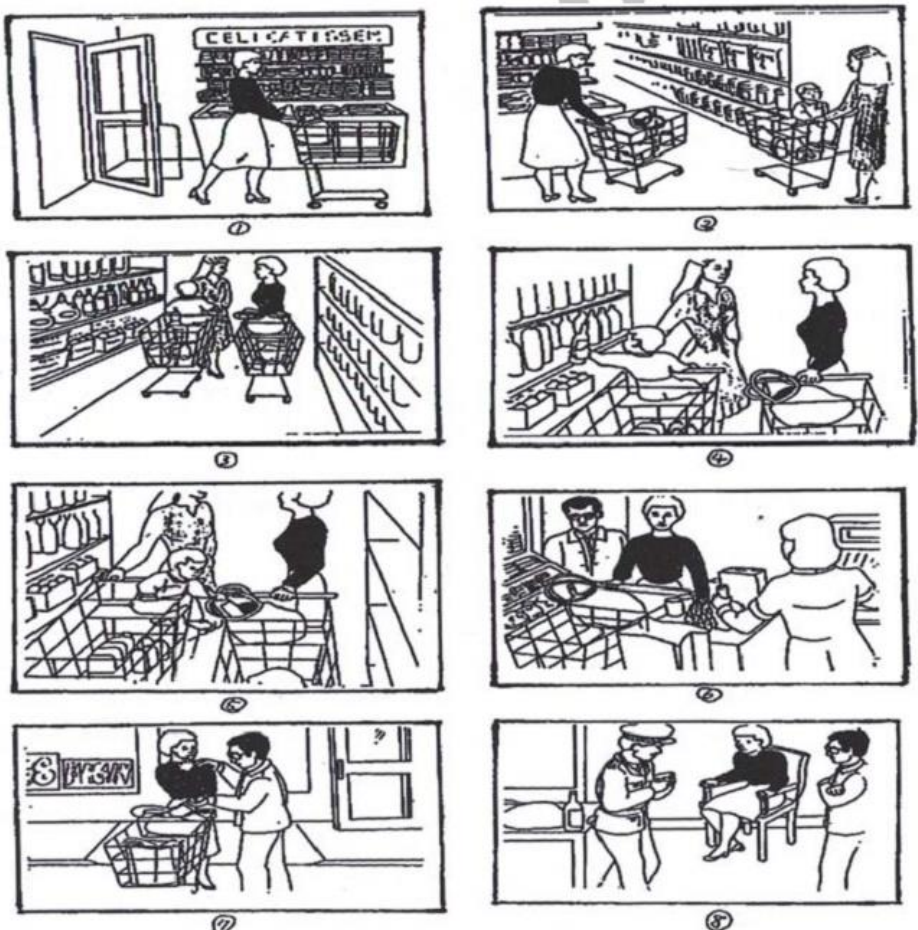

\section{REFERENCES}

Abdi Tabari, M. (2016). The effects of planning time on complexity, accuracy, fluency, and lexical variety in L2 descriptive writing. Asian Pacific Journal of Second and Foreign Language Education, 1(10), 1-15. https://doi.org/10.1186/s40862-016-0015-6

Abdollahzadeh, S., \& Fard Kashani, A. (2011). The effect of task complexity on EFL learners' narrative writing task performance. Journal of English Language Teaching and Learning, $8,1-28$.

Ahmadian, M. (2012). The effects of guided careful online planning on complexity, accuracy and fluency in intermediate EFL learners' oral production: The case of English articles. Language Teaching Research, 16(1), 129-149. https://doi.org/10.1177/1362168811425433

Ahmadian, M., \& Tavakoli, M. (2011). The effects of simultaneous use of careful online planning and task repetition on accuracy, complexity, and fluency in EFL learners. Language Teaching Research, 15(1), 35-59. https://doi.org/10.1177/1362168810383329 
Ahmadian, M. J., Tavakoli, M., \& Vahid Dastjerdi, H. (2015). The combined effects of online planning and task structure on complexity, accuracy and fluency of L2 speech. The Language Learning Journal, 43(1), 41-56. https://doi.org/10.1080/09571736.2012.681795

Arent, R. (2003). Promoting revision and development in L2 writing through a combinationbased curriculum. The Korea TESOL Journal, 6(1), 1-26.

Baleghizadeh, S. \& Nasrollahi Shahri, M. N. (2013). The effect of online planning, strategic planning and rehearsal across two proficiency levels. The Language Learning Journal, 45(2), 1-14. https://doi.org/10.1080/09571736.2013.808258

Crooks, G. (1989). Planning and interlanguage variation. Studies in Second Language Acquisition, 11, 367-383. https://doi.org/10.1017/S0272263100008391

DeKeyser, R. (2003). Implicit and explicit learning. In C. Doughty \& M. Long (Eds.), Handbook of second language acquisition (pp. 313-349). Malden, MA: Blackwell.

Elder, C., \& Iwashita, N. (2005). Planning for test performance: Does it make a difference? In R. Ellis (Ed.), Planning and task performance in a second language (pp. 219-238). Amsterdam: John Benjamins.

Ellis, R. (2005). Planning and task-based performance. In R. Ellis (Ed.), Planning and task performance in a second language. Amsterdam, Philadelphia: John Benjamins.

Ellis, R. (2009). The differential effects of three types of task planning on the fluency, complexity, and accuracy in L2 oral Production. Applied Linguistics, 30 (4), 474-509. https://oi.org/10.1093/applin/amp042

Ellis, R., \& Barkhuizen, G. (2005). Analyzing learner language. Oxford: Oxford University Press.

Ellis, R., \& Yuan, F. (2004). The effects of planning on fluency, complexity and accuracy in second language narrative writing. Studies in Second Language Acquisition, 26, 59-84. https://doi.org/10.1017/S0272263104026130

Færch, C., \& Kasper, G. (1983). Plans and strategies in foreign language communication. In C. Færch \& G. Kasper (Eds.), Strategies in inter-language communication (pp. 20-60). London: Longman.

Foster, P., \& Skehan, P. (1996). The influence of planning on performance in task-based learning. Studies in Second Language Acquisition, 18(3), 299-324. https://doi.org/10.1017/S0272263100015047

Ghavamnia, M., Tavakoli, M., \& Esteki, M. (2013). The effect of pre-task and online planning conditions on complexity, accuracy, and fluency on EFL learners' written production. Porta Linguarum, 20, 31-43.

Gilabert, R. (2007). Effects of manipulating task complexity on self-repair during L2 oral performance. IRAL, (45), 215-240. https://doi.org/10.1515/iral.2007.010

Ishikawa, T. (2006). The effects of task complexity and language proficiency on task-based language performance. The Journal of Asia TEFL, 3(4), 193-225.

Iwashita, N., Elder. C., \& McNamara, T. (2001). Can we predict task difficulty in an oral proficiency test? Exploring the potential of an information-processing approach to task design. Language Learning, 51 (3), 401- 436. https://doi.org/10.1111/0023-8333.00160

Kawauchi, C. (2005). The effects of strategic planning on the oral narratives of learners with low and high intermediate proficiency in R. Ellis (Ed.), Planning and task-performance in a second language (pp. 143-164). Amsterdam/Philadelphia: John Benjamins.

Kim, Y., \& Tracy-Ventura, N. (2013). The role of task repetition in L2 performance development: What needs to be repeated during task-based interaction? System, 41, 829-840. https://doi.org/10.1016/j.system.2013.08.005 
Khomeijani Farahani, A., \& Meraji, S. R (2011). Cognitive task complexity and L2 narrative writing performance. Journal of Language Teaching and Research, 2(2), 445-456. https://doi.org/ 10.4304/jltr.2.2.445-456

Larsen-Freeman, D. (2006). The emergence of complexity, fluency, and accuracy in the oral and written production of five Chinese learners of English. Applied Linguistics. 27(4), 590619. https://doi.org/10.1093/applin/aml029

Li, L., Chen, J., \& Sun, L. (2015). The effects of different lengths of pretask planning time on L2 learners' oral test performance. TESOL Quarterly, 49(1), 38-66. https://doi.org/10.1002/tesq.159

Markee, N., \& Kunitz, S. (2013). Doing planning and task performance in second language acquisition: An ethnomethodological respecification. Language Learning, 63(4), 629-664. https://doi.org/10.1111/lang.12019

Mclaughlin, B., \& Heredia, R. (1996). Information-processing approaches to research on second language acquisition and use. In W. Ritchie \& T. Bhatia (Ed.), Handbook of second language acquisition ((pp. 213-228). San Diego: Academic Press.

Mehnert, U. (1998). The effects of different lengths of time for planning on second language performance. Studies in Second Language Acquisition, 20, 52-

83. https://doi.org/10.1017/S0272263198001041

Mochizuki, N., \& Ortega, L. (2008). Balancing communication and grammar in beginning level foreign language classrooms: A study of guided planning and relativization. Language Teaching Research, 12,11-37. https://doi.org/10.1177/1362168807084492

Nasiri, M., \& Atai, M. R. (2017). An investigation into the effects of joint planning on complexity, accuracy, and fluency across task complexity. Journal of English Language Teaching and Learning, 9(20), 49-74.

Ojima, M. (2006). Concept mapping as pre-task planning: A case study of three Japanese ESL writers. System, 34(4), 566-585. https://doi.org/10.1016/j.system.2006.08.003

Ong, J. (2014). How do planning time and task conditions affect metacognitive processes of L2 writers? Journal of Second Language Writing, 23, 17-30. https://doi.org/10.1016/i.jslw.2013.10.002

Ortega, L. (1999). Planning and focus on form in L2 oral performance. Studies in Second Language Acquisition, 21, 109-118. https://doi.org/10.1017/S0272263199001047

Richards, J., Platt, J., \& Platt, H. (1996). Dictionary of language teaching and applied linguistics. London: Longman.

Sangarun. J. (2001). The Effects of pre-task planning on foreign language performance. Doctoral thesis, University of Toronto, Canada.

Sangarun, J. (2005). The effects of focusing on meaning and form in strategic planning. In R. Ellis (Ed.), Planning and task Performance in a second language (pp. 111-142). Amsterdam, Philadelphia: John Benjamins.

Skehan, P. (1996). A framework for the implementation of task-based instruction. Applied Linguistics, 17, 38-62. https://doi.org/10.1093/applin/17.1.38

Skehan, P., \& Foster. P. (1977). Task type and task processing conditions as influences on foreign language performance. Language Teaching Research, 1(3), 185-211. https://doi.org/10.1177/136216889700100302

Tavakoli, P., \& Foster, P. (2011). Task design and second language performance: the effect of narrative type on learner output. Language Learning. 61, 37-72.

https://doi.org/10.1111/j.1467-9922.2008.00446.x 
Tavakoli, P., \& Skehan, P. (2005). Strategic planning, task structure and performance testing. In R. Ellis (Ed.), Planning and task performance in a second language (pp. 239-277). Amsterdam: Benjamins.

Van Patten, B. (1990). Attending to content and form in the input: an experiment in consciousness. Studies in Second Language Acquisition, 12, 287-301. https://doi.org/10.1017/S0272263100009177

Wang, Y. (2008). Influence of planning on students' language performance in task-based language teaching. English language Teaching, 1 (1), 83-86. https://doi.org/10.5539/elt.v1n1p83

Wendel, J. N. (1997). Planning and second-language narrative production. Doctoral Thesis. Temple University.

Wigglesworth, G. (1997). An investigation of planning time and proficiency level on oral test discourse. Language Testing, 14, 85-106. https://doi.org/10.1177/026553229701400105

Wigglesworth, G., \& Storch, N. (2009). Pair versus individual writing: Effects on fluency, complexity and accuracy. Language Testing, 26(3), 445-466.

https://doi.org/10.1177/0265532209104670

Williams, J. (1992). Planning, discourse marking, and the comprehensibility of international teaching assistants. TESOL Quarterly, 26, 693-711. https://doi.org/10.2307/3586869

Yuan, F. \& Ellis, R. (2003). The effects of pre-task planning and on-line planning on fluency, complexity, and accuracy in L2 monologic oral production. Applied Linguistics. 24(1), 127. https://doi.org/10.1093/applin/24.1.1

Yule, G. (1997). Referential communication tasks. Mahwah, NJ: Lawrence Erlbaum.

\section{AREZOO ASHOORI TOOTKABONI}

Received her PhD in applied linguistics from Allameh Tabataba'i University of Tehran, Iran in 2018. She been a lecturer, running Language Teaching Methodology, Language Testing, Reading Comprehension, Speaking and Listening and General English courses at state universities in Iran since 2011.

\section{MARYAM PAKZADIAN}

Received received her PhD in applied linguistics from Allameh Tabataba'i University of Tehran, Iran in 2017. She has taught diferent graduate and undergraduate courses in Iranian universities since 2009. Her áreas of interest are Discourse Analysis and Interlanguage Pragmatics,EIL, identity and motivation. 
Tootkaboni, A. A. \& Pakzadian, M. (2020). Exploring the effects of pre-task planning time on EFL learners' narrative writing. Bellaterra Journal of Teaching \& Learning Language \& Literature, 13(4), e851. https://doi.org/10.5565/rev/jtl3.851

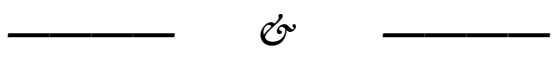

Rebut / Recibido / Received / Reçu 04-11-2019

Acceptat / Aceptado / Accepted / Accepté: 28-09-2020 